\title{
POTENSI INTEGRASI PROGRAM SKRINING HIPOTIROID PADA NEONATAL DI DAERAH REPLETE DEFISIENSI IODIUM
}

\author{
Feasibility of Program Integration in Neonatal Hypothyroid Screening in Replete \\ lodine Deficiency Area
}

\author{
Leny Latifah ${ }^{1 *}$, Ika Puspita Asturiningtyas ${ }^{1}$, Yusi Dwi Nurcahyani ${ }^{1}$, Hadi Ashar ${ }^{1}$, Prihatin Broto Sukandar ${ }^{1}$ \\ 'Balai Penelitian dan Pengembangan Kesehatan Magelang \\ Kapling Jayan, Borobudur, Magelang, Jawa Tengah, Indonesia \\ *e-mail: lenylatifah1@gmail.com
}

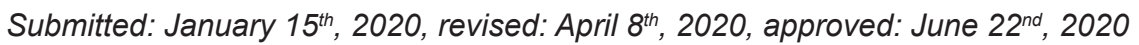

\begin{abstract}
Background. Higher prevalence of congenital hypothyroid $(\mathrm{CH})$ problems in infants born in lodine Deficiency Disorders (IDD) endemic areas make early detection and intervention of infants hypothyroid problems critical. No research found on Neonatal Hypothyroid Index (NHI) screening implementation and hypothyroid screening integration feasibility. Objective. Identify the infant hypothyroid screening program and analyze the feasibility of program integration in lodine Deficiency Disorders (IDD) endemic area. Method. This was qualitative research conducted in Magelang District. Data collected through semi-structured interviews in 14 informants, consisted of program in charge of District Health Officer (DHO) level, Public Health Center (PHC) level, and program implanter. Interviews are recorded by digital recording devices, transcripted, and analyzed using content analysis. Data trustworthiness obtained through source triangulation. Results. Two congenital hypothyroid screening programs in Magelang District identified, Congenital Hypothyroid Screening (CHS) and NHI Screening program. Program enabling factors were policy and implementation. Program policies are CHS funding commitment for 500 babies/year and NHI screening for each newborn. Programs were integrated through Integrated Management of Young Infants (IMYI) program. CHS and NHI programs implemented by midwives and nutritionist integrated with IMYI, and posyandu at higher age. The program inhibiting factors were supervision/coordination lack, and village midwives have not received $\mathrm{CHS}, \mathrm{NHI}$, or IMYI training. The $\mathrm{CH}$ cases referral procedure still unclear. The screening found $\mathrm{CH}$ cases. Conclusion. Early detection of congenital hypothyroidism implemented in Magelang district. Budget constraints cause CHS covering only small number of targets, then covered universally in NHI screening. IMYI integration implemented in enactment, reporting, and NHI form attachment. Integrated hypothyroid screening with $\mathrm{IMYI}$ is feasible and proven by the $\mathrm{CH}$ case finding. Program integration needs to be expanded by integrating NHI, CHS, and IMYI skills enhancement for village midwives.
\end{abstract}

Keywords: infant, integration, neonatal hypothyroidism, screening

\begin{abstract}
ABSTRAK
Latar Belakang. Prevalensi hipotiroid kongenital (HK) lebih tinggi di daerah endemik Gangguan Akibat Kekurangan lodium (GAKI) menyebabkan deteksi dan intervensi dini hipotiroid bayi menjadi penting. Belum ditemukan penelitian pelaksanaan skrining dengan Neonatal Hypothyroid Index $(\mathrm{NHI})$ serta potensi integrasi skrining hipotiroid. Tujuan. Mengidentifikasi program skrining hipotiroid bayi di daerah endemik GAKI dan menganalisis potensi integrasinya. Metode. Penelitian ini adalah penelitian kualitatif yang dilaksanakan di Kabupaten Magelang. Data diambil dengan wawancara mendalam semi terstruktur pada 14 informan terdiri dari penanggung jawab program tingkat Dinas Kesehatan Kabupaten (DKK) Magelang, puskesmas, dan pelaksana program. Dinas Kesehatan dan 4 Puskesmas di Kabupaten Magelang menjadi informan penelitian. Wawancara
\end{abstract}


direkam dengan alat perekam digital, disusun dalam transkrip, dianalisis menggunakan analisis isi (content analysis). Trustworthiness data diperoleh melalui triangulasi sumber. Hasil. Terdapat dua program skrining hipotiroid kongenital di Kabupaten Magelang, yaitu Skrining Hipotiroid Kongenital (SHK) dan skrining dengan form NHI. Faktor pemungkin keberhasilan program bersumber kebijakan dan implementasi. Komitmen pendanaan mandiri SHK melalui APBD pada 500 bayi per tahun, skrining form $\mathrm{NHI}$ pada setiap bayi baru lahir, dan integrasi pelaksanaannya melalui program managemen terpadu bayi muda (MTBM). Program SHK dan NHI telah diimplementasikan bidan desa dan petugas gizi terintegrasi MTBM, pada usia lebih tinggi di posyandu. Faktor penghambatnya, dari sisi SDM adalah kurangnya supervisi/koordinasi serta bidan desa pelaksana belum mendapatkan pelatihan SHK, NHI, maupun MTBM. SOP rujukan penemuan kasus HK belum jelas. Hasil skrining berhasil menemukan kasus HK. Kesimpulan. Deteksi dini hipotiroid kongenital telah dilakukan di Kabupaten Magelang. Keterbatasan anggaran menyebabkan SHK mencakup sebagian kecil sasaran, kemudian dijangkau dengan skrining NHI semua neonatus. Integrasi MTBM dilakukan dalam pelaksanaan, pelaporan, dan melampirkan form NHI dalam pemeriksaan MTBM. Fisibilitas integrasi terbukti dalam penemuan kasus HK dengan $\mathrm{NHI}$ terintegrasi MTBM. Integrasi program perlu diperluas dengan mengintegrasikan pelatihan $\mathrm{NHI}, \mathrm{HK}$, dan MTBM untuk pengembangan keterampilan bidan pelaksana program.

Kata kunci: bayi, integrasi, hipotiroid neonatal, skrining

\section{PENDAHULUAN}

Kekurangan iodium adalah masalah kesehatan masyarakat yang berdampak luas. Secara global, diperkirakan 35 persen atau dua miliar orang memiliki asupan iodium yang tidak mencukupi. lodium merupakan zat gizi mikro yang berperan penting dalam pembentukan hormon tiroid. Meskipun gondok adalah dampak kekurangan iodium yang paling terlihat, dampak utama hipotiroidisme akibat defisiensi iodium adalah gangguan perkembangan saraf, khususnya di awal kehidupan. Pada janin, hormon tiroid yang tidak memadai mengganggu proses mielinisasi, migrasi sel, diferensiasi, dan pematangan sel otak. Program penanggulangan defisiensi iodium telah mencapai keberhasilan di banyak negara, tetapi proporsi penduduk tidak terproteksi kekurangan iodium yang masih besar menyebabkan banyak anak di daerah defisiensi iodium masih berpotensi mengalami masalah perkembangan. ${ }^{1-3}$ Defisiensi iodium merupakan salah satu penyebab minor hipotiroid kongenital. Penelitian di India, Iran, Israel, dan Turki menunjukkan insidensi hipotiroid kongenital lebih tinggi di daerah endemik defisiensi iodium. ${ }^{4-8}$ Hipotiroidisme kongenital dan defisiensi iodium endemik adalah penyebab paling utama retardasi mental yang dapat dicegah. ${ }^{9}$ Belum ada data tentang prevalensi hipotiroid kongenital di Kabupaten Magelang, tetapi penelitian pada anak usia di bawah dua tahun di Kabupaten Magelang, Wonosobo, Purworejo, dan Temanggung (Jawa Tengah), serta Situbondo dan Jember (Jawa Timur) yang merupakan daerah replete defisiensi iodium menemukan bahwa 18,1 persen dari 315 anak di bawah dua tahun yang diperiksa mengalami masalah hipotiroid. Data tersebut menunjukkan bahwa prevalensi masalah hipotiroid pada anak di daerah replete defisiensi iodium masih cukup tinggi ${ }^{10}$ dibandingkan prevalensi yang dilaporkan di beberapa negara, terutama di daerah endemik GAKI. ${ }^{4-8}$

Kerentanan masalah perkembangan pada anak-anak dari daerah defisiensi iodium perlu ditangani dengan pendekatan sistematis. Deteksi dan intervensi dini masalah perkembangan anak, kretinisme, dan hipotiroid kongenital yang prevalensinya lebih tinggi di daerah dengan riwayat defisiensi iodium memerlukan kerangka kerja yang terintegrasi untuk mengoptimalkan pertumbuhan dan perkembangan anak di daerah dengan riwayat defisiensi iodium. Deteksi dini kasus hipotiroid telah dijadikan program 
Kementerian Kesehatan melalui Skrining Hipotiroid Kongenital (SHK) yang ditetapkan dalam Peraturan Menteri Kesehatan (PMK) Nomor 78 Tahun 2014, dan skrining tanda klinis hipotiroid dengan Neonatal Hypothyroid Index $(\mathrm{NHI})$ yang tertuang dalam Pedoman Deteksi Dini Kretin bagi Petugas Kesehatan. ${ }^{11,12}$

Meskipun target pelaksanaan SHK adalah universal pada setiap bayi yang baru lahir, tetapi sampai saat ini masih belum terlaksana karena berbagai keterbatasan, terutama persetujuan pendanaan. Pada pelaksanaannya, hasil penelitian menunjukkan masih ditemukan berbagai masalah dalam operasionalisasi pelaksanaan SHK. Deteksi dini melalui SHK belum menjadi program rutin pemerintah sehingga banyak kasus hipotiroid kongenital yang belum dapat dikelola secara tepat dan berkesinambungan. ${ }^{13}$ Studi evaluasi SHK di Provinsi Daerah Istimewa Yogyakarta (DIY) menunjukkan setelah berjalan hampir 10 tahun, cakupan bayi yang menjalani SHK masih sangat rendah, atau hanya sekitar 10 persen. Ketepatan waktu diagnosis hipotiroid kongenital juga masih sangat terlambat. Alur jejaring kerja sama program SHK yang kurang efisien mengakibatkan keterlambatan waktu pelayanan, terutama pada waktu penyampaian dan tindak lanjut hasil tes SHK. ${ }^{14}$ Penelitian di Malang menunjukkan bahkan dengan keterbatasan cakupan sampling SHK, cukup banyak sampel SHK yang kurang memenuhi syarat sehingga tidak dapat dilakukan analisis. ${ }^{15}$

Lampiran PMK Nomor 78 Tahun 2014 menyebutkan rencana pengembangan program SHK. Tahun 2008 dilakukan studi pendahuluan SHK di 8 provinsi, tahun 2013 SHK dilaksanakan di 11 provinsi. Pada akhir tahun 2019 diharapkan seluruh provinsi di Indonesia sudah melaksanakan SHK. Perluasan cakupan program SHK dilakukan secara bertahap. Selanjutnya program SHK diperluas jangkauannya ke provinsi lain dengan memperhatikan adanya kantong- kantong wilayah dengan defisiensi iodium, ketersediaan infrastruktur, dan sumber daya lain. ${ }^{16} \mathrm{Hal}$ ini menunjukkan bahwa berdasarkan kebijakan dan keterbatasan cakupan SHK, daerah endemik GAKI menjadi prioritas. Skrining tanda klinis hipotiroid kongenital menjadi salah satu upaya mendeteksi masalah kretin ketika SHK belum terlaksana secara universal, seperti yang tercantum dalam Pedoman Deteksi Dini Kretin bagi Petugas Kesehatan. ${ }^{17}$

Beberapa penelitian yang melakukan evaluasi program deteksi dan intervensi dini menunjukkan salah satu kendala utama pelaksanaan program adalah beban kerja tenaga kesehatan yang tinggi, sehingga program tidak terlaksana dengan baik. ${ }^{16,18}$ Integrasi antar program kesehatan menjadi salah satu solusi agar program dapat terlaksana dengan baik. Masih sedikit penelitian yang mengevaluasi pelaksanaan SHK di berbagai daerah di Indonesia dan belum ada penelitian yang mengevaluasi pelaksanaan skrining $\mathrm{NHI}$ di daerah dengan riwayat defisiensi iodium, serta kemungkinan integrasi SHK dan $\mathrm{NHI}$ dengan program lain. Penelitian ini bertujuan untuk melihat faktor pendukung dan penghambat dalam program skrining hipotiroid kongenital guna menentukan fisibilitas pelaksanaan program. Perhatian khusus diberikan pada potensi integrasi pelaksanaan skrining hipotiroid, baik integrasi SHK dan NHI, maupun integrasi dengan program lain.

\section{METODE}

Penelitian ini adalah penelitian kualitatif dan merupakan bagian dari penelitian berjudul Pertumbuhan dan Perkembangan Anak di Daerah Replete dan Non Replete Defisiensi lodium di Kabupaten Magelang Tahun 2016. Pengambilan data dilakukan dengan wawancara mendalam semi terstruktur terhadap 15 orang yang terdiri dari penanggung jawab program di tingkat kabupaten dan puskesmas serta 
pelaksana program di tingkat desa. Wawancara dilakukan oleh tim peneliti dari Balai Litbangkes Magelang dengan latar belakang pendidikan kesehatan masyarakat, dokter, dan psikolog. Wawancara dilakukan dalam durasi 60-120 menit untuk masing-masing reponden. Informed consent diberikan secara tertulis sebagai persetujuan responden untuk terlibat dalam penelitian. ${ }^{19}$ Wawancara direkam dengan alat perekam digital, disusun dalam bentuk transkrip, dan dianalisis dengan menggunakan analisis isi (content analysis). Analisis isi adalah sebuah metode penelitian dengan menggunakan seperangkat prosedur untuk membuat inferensi yang valid dari teks. ${ }^{20}$ Alur analisis mengacu pada 4 tahap analisis isi dari Bengtsson. ${ }^{21}$

Tahap 1 yaitu dekontekstualisasi. Peneliti melakukan pengenalan data dengan cara membaca transkripsi data secara menyeluruh untuk memperoleh insights sebelum dipecah ke dalam unit analisis lebih kecil yang bermakna dalam menjawab pertanyaan penelitian. Tahap 2 adalah rekontekstualisasi. Dilakukan coding untuk menentukan unit-unit kecil yang bermakna. Kemudan peneliti melakukan pengecekan kembali apakah semua aspek content/isi telah tercakup dalam menjawab tujuan. Dilakukan pengecekan ulang terhadap keseluruhan transkrip untuk melihat apakah ada kutipan bermakna yang terlewatkan. Tahap 3 adalah kategorisasi. Peneliti menentukan unit makna yang lebih meluas. Data dapat dibagi berdasarkan tujuan umum dan tujuan spesifik pada saat data dikumpulkan, atau asumsi teoritis berdasarkan literatur. Pada penelitian ini pedoman kategorisasi data adalah tujuan penelitian. Pada proses kategorisasi, tema dan kategori diidentifikasi. Sub-kategori merupakan unit pemaknaan yang terkecil. Proses kategorisasi berakhir ketika data menjawab tujuan penelitian dan penjelasan yang bermakna diperoleh.
Tahap 4 adalah kompilasi. Setelah kategori ditetapkan, proses analisis dan penulisan dimulai. Salah satu perbedaan antara berbagai metode analisis kualitatif adalah bagaimana peneliti berhubungan dengan proses analisis itu sendiri dan beradaptasi dengan hasilnya. Ketika melakukan content analysis secara kualitatif, peneliti menganalisis data yang dikumpulkan dari perspektif netral dan mempertimbangkan objektivitasnya. Peneliti bekerja dengan cara ini secara bertahap melalui setiap kategori yang diidentifikasi dan melalui tema dalam analisis laten. Dalam analisis manifes, peneliti sering menggunakan kata-kata informan, dan tetap sadar akan perlunya merujuk kembali ke teks asli. Dengan cara tersebut, dimungkinkan untuk tetap dekat dengan makna dan konteks asli. Sebaliknya, pada analisis laten, peneliti membenamkan diri dalam batas tertentu dalam data untuk mengidentifikasi makna tersembunyi dalam teks. Setiap kategori atau tema, peneliti memilih unit makna yang sesuai untuk disajikan dalam teks yang dibahas sebagai kutipan. Meskipun analisis isi memungkinkan untuk dilakukan kuantifikasi, tetapi dalam penelitian ini, dipilih analisis isi secara kualitatif. ${ }^{20-22}$

Untuk menjamin trustworthiness, triangulasi dilakukan dengan cara memperoleh data dari 3 perspektif sumber, yaitu penanggung jawab program di tingkat kabupaten, penanggung jawab program puskesmas, dan pelaksana di tingkat desa. Informan penelitian terdiri dari 3 level, yaitu penanggung jawab program di tingkat kabupaten, penanggung jawab program di tingkat puskesmas, dan pelaksana program di tingkat puskesmas dan desa. Informan di tingkat Dinas terdiri dari 2 orang, yaitu Kepala Seksi Kesejahteraan Keluarga dan Kepala Seksi Gizi Dinas Kesehatan Kabupaten Magelang. Informan lainnya adalah 5 penanggung jawab program di tingkat puskesmas terdiri dari kepala puskesmas dan bidan koordinator, serta 8 pelaksana program di tingkat puskesmas terdiri dari bidan desa dan petugas gizi dari 4 puskesmas di 
Kabupaten Magelang. Saturasi data diperoleh ketika tidak ada kebaruan data dari informan. Trustworthiness data juga dilakukan pada tahap analisis dengan melakukan tahapan analisis sesuai prosedur analisis isi secara kualitatif. Etik penelitian diperoleh dari komisi etik Badan Penelitian dan Pengembangan Kesehatan, Kementerian Kesehatan RI.

\section{HASIL}

\section{A. Faktor Pemungkin}

\section{Kebijakan Program}

Deteksi dini kasus hipotiroid di Kabupaten Magelang dilakukan melalui program skrining dengan menggunakan NHI dan SHK. Pemerintah Kabupaten Magelang memiliki komitmen yang kuat dalam melakukan deteksi dini hipotiroid kongenital. Komitmen tersebut ditunjukkan dengan adanya program deteksi dini hipotiroid kongenital melalui NHI dan SHK. Pogram skrining $\mathrm{NHI}$ merupakan program yang dilakukan terhadap bayi baru lahir di daerah endemik GAKI. Kabupaten Magelang juga berinisiatif mengeluarkan kebijakan untuk melakukan pemeriksaan $\mathrm{NHI}$ bagi bayi baru lahir. Menurut Kepala Seksi (kasie) A, program skrining $\mathrm{NHI}$ merupakan program yang diinstruksikan oleh Dinas Kesehatan Provinsi Jawa Tengah terhadap bayi baru lahir di daerah endemik GAKI. Namun berdasarkan penuturan dari Kepala Seksi (kasie) B, program ini merupakan inisiatif dari pemerintah Kabupaten Magelang dalam upaya mengeliminasi kretin. Program skrining dengan menggunakan form $\mathrm{NHI}$ wajib dilakukan oleh bidan desa. $\mathrm{NHI}$ dilakukan saat kunjungan neonatal oleh bidan desa bersamaan dengan Manajemen Terpadu Balita Muda (MTBM).

"NHI sudah masuk pemeriksaan standar untuk bayi baru lahir di Jawa Tengah khusus di daerah endemik GAKl" ( kasie A)

"Kebijakan/inisiatif dari kabupaten Magelang" ( kasie B)
"Kita mewajibkan semua bidan yang menolong persalinan harus menggunakan $\mathrm{NHI}$, sudah ada blangko NHI..sudah satu paket. Untuk kunjungan neonatal itu buku KIA, NHI sama MTBM (Manajemen terpadu balita muda)" ( kasie A)

Kabupaten Magelang juga memiliki komitmen yang kuat untuk tetap melaksanakan SHK dengan sumber pendanaan dari APBD II, karena sudah tidak mendapatkan alokasi anggaran dari Pemerintah Pusat. Dana yang tersedia untuk SHK dari APBD II adalah untuk pemeriksaan 500 bayi setiap tahunnya. Deteksi dini hipotiroid melalui program SHK juga dilakukan pada bayi baru lahir usia 3-5 hari. Namun, pemegang program di dinas kesehatan juga memberi kelonggaran pengambilan darah sampai maksimal usia 1 bulan.

"Jadi tolong SHK jangan sampai stop.
Sebetulnya kemaren mbok ditambahi,
jangan segitu [500 bayi/tahun] bayi kita
kan banyak" (Kasie A)
"2 sampai 5 hari.. kalau tidak bisa ya
sampai 1 bulan...maksimalnya" (Kasie
B)

\section{Implementasi Program}

Program deteksi dini hipotiroid melalui $\mathrm{NHI}$ maupun SHK merupakan tanggung jawab dari petugas gizi di puskesmas. Pelaksana di lapangan adalah bidan desa. Bidan desa melakukan $\mathrm{NHI}$ saat melakukan kunjungan neonatal pada usia bayi ke-0. Bidan desa memeriksa tanda-tanda hipotiroid kongenital pada bayi sesuai dengan yang ada di form $\mathrm{NHI}$.

"Ya kalau pas KN itu kan mesti diperiksa keseluruhan to, dari neteknya, dari buang air besarnya terus dari pusernya juga. Nek buang air besar nya kan sembelit apa enggak, bodong apa enggak trus melet2 gitu. Kulitnya kasar bersisik apa enggak, trus mungkin wajahnya juga agak gimana itu" (Bidan Koordinator B) 
SHK juga dilakukan oleh bidan desa saat kunjungan neonatal. Selain dilakukan pada saat kunjungan neonatal, pengambilan darah juga ada yang dilakukan di puskesmas. Bidan desa menyarankan orang tua bayi membawa bayinya ke puskesmas untuk dilakukan pengambilan darah. Proses pengambilan darah sudah dilakukan pada rentang 3 hari sejak bayi dilahirkan, sesuai dengan arahan dari dinas kesehatan. Darah yang diambil kemudian dikumpulkan ke petugas gizi untuk kemudian diserahkan ke dinas kesehatan. Pelaporan program SHK juga dilakukan oleh petugas gizi.

"3 hari, protap dari dinas 3 hari sampai berapa agak lupa. Kemudian ada proses informed consent. Ada bayi yang dibawa kesini, petugas yang ngambil, yang piket. Ada juga yang didatangi bersama petugas gizi, kalo dulu saya sendiri, saya Bikor [Bidan Koordinator] kan keliling sekarang banyak gawean"(Bidan Koordinator C) "lya...hanya mengambil darah. Iya..nanti kan hasilnya pemeriksaan dilaporkan bu $D$ [petugas gizi]" (Bidan Koordinator D)

\section{Integrasi Program}

Program skrining hipotiroid kongenital baik melalui NHI maupun SHK, secara program sudah diintegrasikan dalam Manajemen Terpadu Bayi Muda (MTBM). Dalam MTBM, salah satu tata laksana yang wajib dilakukan adalah deteksi dini hipotiroid kongenital melalui form $\mathrm{NHI}$ saat bidan melakukan kunjungan neonatal.

"Kita mewajibkan semua bidan yang menolong persalinan harus menggunakan $\mathrm{NHI}$, sudah ada blangko $\mathrm{NHI}$... sudah satu paket. Untuk kunjungan neonatal itu buku KIA, NHI sama MTBM (Manajemen terpadu balita muda)" (Kasie Kesga)

Pelaksana di lapangan kegiatan deteksi dini tumbuh kembang maupun deteksi dini hipotiroid kongenital melalui $\mathrm{NHI}$ dan SHK adalah bidan desa. Saat kunjungan neonatal, bidan desa wajib melakukan skrining NHI. Bayi yang lahir saat ada program SHK, maka dilakukan pengambilan darah oleh bidan untuk skrining SHK, jika kuotanya masih mencukupi. Meskipun pelaksana skrining $\mathrm{NHI}$ dan SHK di lapangan adalah bidan desa, tetapi pelaporannya ke petugas gizi.

"NHI itu wajib, kita mewajibkan pada bidan yang menolong persalinan..sudah termasuk SOP". "Begitu lahir itu.. semua bayi baru lahir langsung dilihat, disitu kan ada kunjungan bidan.. kunjungan neonatal $(K N)$ tiga kali 1,2,3 dipantau terus sampai usia 28 hari" (Kasie A)

"Ya itu, kita kalo NHI kan awal usia langsung, kalo DDTK semua kita lakukan sesuai dengan umur. Kalo untuk SHK ya itu tadi tergantung masih ada jatah ato ndak, kalo masih kita langsung ambil pada sesuai usianya" (Kasie A)

Petugas gizi di beberapa wilayah ikut secara langsung dalam melakukan kunjungan neonatal, terutama jika bersamaan dengan pengambilan darah untuk SHK. Petugas gizi tidak melakukan pengambilan sampel, hanya ikut mendampingi sebagai pihak yang bertanggung jawab terhadap pelaksanaan SHK. Biasanya petugas gizi juga ikut ke lapangan jika pasien memiliki pengetahuan yang kurang, sehingga dapat diberikan penjelasan lebih dari petugas gizi.

"Ya di kunjungan neonatal.. kunjungan. kadang kalau pasien pengetahuannya kurang ya kunjungan rumah, bidan bersama petugas gizi ato dengan bidan koordinator" (Bidan Koordinator C)

"Untuk pengambilan darah oleh bidan dan saya yang mendampingi nanti saya yang ngirim" (Petugas gizi $C$ )

Jika pada saat kunjungan neonatal bidan tidak menemukan adanya tanda-tanda yang mengarah pada hipotiroid kongenital, maka posyandu dijadikan sarana untuk mendeteksi hipotiroid kongenital. Pada usia lebih tinggi, melalui posyandu dimungkinkan integrasi 
program deteksi dini tumbuh kembang anak dan deteksi dini hipotiroid. Pada beberapa kasus, gejala hipotiroid kongenital tidak terlihat di awal kelahiran. Bidan dapat mendeteksi hipotiroid kongenital pada saat kunjungan bayi ke posyandu. Melalui tanda fisik dan perkembangan balita, maka dapat dilanjutkan dengan skrining $\mathrm{NHI}$ jika memang menunjukkan kemungkinan gejala yang mengarah kepada hipotiroid kongenital.

"kalo di Posyandu kan kelihatan kalo ada anak yang mengalami keterlambatan" (Bidan A)

Program SHK juga dilakukan pada saat kunjungan neonatal. Kedua program deteksi dini hipotiroid baik melalui form $\mathrm{NHI}$ maupun SHK dilakukan oleh bidan desa pada saat kunjungan neonatal.

"Selalu ada kerjasama antara bidan dan petugas gizi. Integrasi program NHI dengan kunjungan neonatus" (Kasie Gizi)

\section{Penemuan Kasus Hipotiroid Kongenital di Kabupaten Magelang: Integrasi NHI dengan MTBM}

Pada waktu penelitian ini berlangsung, klinik Balai Penelitian dan Pengembangan Gangguan Akibat Kekurangan lodium (BP2GAKI Magelang) mencatat temuan kasus hipotiroid kongenital berdasarkan rujukan Puskesmas Sawangan yang menjadi salah satu lokasi penelitian. Penelusuran data lebih lanjut dilakukan. Hasil wawancara dengan bidan desa dan bidan koordinator Puskesmas menemukan bahwa pemeriksaan hipotiroid kongenital yang dilakukan bersamaan dengan MTBM terbukti dapat mendeteksi dini hipotiroid kongenital secara dini. Penemuan kasus HK di Puskesmas Sawangan oleh bidan desa diperoleh saat melakukan kunjungan neonatal di hari kedua kelahiran. Saat melakukan kunjungan neonatal, bidan melakukan pemeriksaan panjang badan, tinggi badan, dan lingkar kepala sesuai dengan pedoman deteksi dini tumbuh kembang. Bidan melihat bentuk fisik yang berbeda pada bayi saat kunjungan tersebut, ditambah dengan suara tangisan bayi yang parau, badan lemas, dan tidak bisa menyusu. Bidan kemudian melakukan pemeriksaan $\mathrm{NHI}$ dan didapatkan skor $\mathrm{NHI}$ sebesar 6 poin. Hasil skor tersebut menunjukkan adanya kecurigaan ke arah hipotiroid kongenital, sehingga bidan desa menyarankan pasien untuk diperiksakan ke Klinik BP2GAKI Magelang.

"Ya..bayi lahir dengan PB $45 \mathrm{~cm}$.. menangis parau/tidak keras, lemes, tidak bisa menetek, dari bentuk tubuh agak berbeda dengan bayi lain... Hari kedua, score 6...Karena curiga kelainan, bidan mengajak petugas gizi untuk kunjungan rumah, terus dari hasil pemeriksaan disarankan dirujuk ke BPGAKY, keluarga bersedia, terus dibuatkan rujukan puskesmas" (Bidan Desa D)

Hasil pemeriksaan biokimia dengan TSH bloodspot di klinik BP2GAKI Magelang menunjukkan bayi memiliki kadar TSH sangat tinggi, yang kemudian ditegakkan diagnosis bayi mengalami hipotiroid kongenital dan diberikan pengobatan.

Selain di Sawangan, pengalaman penemuan kasus hipotiroid kongenital melalui $\mathrm{NHI}$ juga pernah ditemukan oleh bidan di Kecamatan Bandongan pada saat melakukan kunjungan neonatal. Bidan menemukan ada tanda fisik yang mengarah ke hipotiroid kongenital pada saat deteksi tumbuh kembang di kunjungan neonatal. Bidan di wilayah kerja Puskesmas Bandongan sudah dibekali dengan keterampilan melakukan skrining $\mathrm{NHI}$, sehingga sudah dapat mengetahui ciri-ciri bayi yang mengalami hipotiroid kongenital. Melalui tanda fisik tersebut, kemudian dilakukan skrining melalui $\mathrm{NHI}$ dan menunjukkan bahwa bayi mengarah ke hipotiroid kongenital. Dari hasil tersebut, bidan merujuk bayi tersebut untuk dilakukan pemeriksaan lanjut di klinik BP2GAKI Magelang. Bayi kemudian 
mendapat terapi dan penanganan di klinik BP2GAKI Magelang.

"NHI nya, pas begitu lahir, kok seperti ini, kita periksa perutnya sampai labianya, mukanya, kita kasih tahu kemudian pengobatan, itu bagus...Trus dikirim ke Borobudur, langsung kita kirim, pengobatan terus, hasilnya bagus bisa sekolah, tapi setelah besar sekolahnya di SLB tapi lumayan, itu jadi ikon dinas" (Bidan Koordinator C)

Penemuan kasus ini menunjukkan bahwa ada potensi sangat besar untuk mengintegrasikan pemeriksaan skrining hipotiroid, dalam hal ini $\mathrm{NHI}$ secara universal, bersamaan dengan pemeriksaan tumbuh kembang. Pada jadwal pemeriksaan skrining/ deteksi dini penyimpangan tumbuh kembang, usia 0 bulan jadwal pemeriksaannya adalah panjang badan (PB), berat badan (BB), dan lingkar kepala (LK). Penemuan kasus HK dengan form $\mathrm{NHI}$ ini bersesuaian dengan jadwal pemeriksaan deteksi dini penyimpangan tumbuh kembang, berupa pemeriksaan panjang badan, berat badan, dan lingkar kepala. Kecamatan Sawangan merupakan daerah dengan riwayat endemik defisiensi iodium, maka penemuan suspect HK dihubungkan dengan masalah gizi mikro iodium. Ketika timbul kecurigaan penemuan kasus kretin, dilakukan integrasi dengan program gizi, dalam hal ini adalah kunjungan rumah dilakukan oleh bidan dengan mengajak petugas gizi. Hal ini bersesuaian dengan kebijakan di Dinas Kesehatan Kabupaten Magelang bahwa pada pelaksanaan SHK dan NHI, dilakukan kerjasama petugas gizi dengan bidan, terutama ketika terjadi penemuan kasus suspect $\mathrm{HK}$, atau di tingkat puskesmas dalam administrasi dan pengiriman sampel.

\section{B. Faktor Penghambat}

\section{Sumber Daya}

Program deteksi dini hipotiroid kongenital melalui $\mathrm{NHI}$ dan SHK juga menemui beberapa kendala dalam pelaksanaannya. NHI seharusnya lebih mudah dilakukan, karena hanya membutuhkan pengetahuan dari petugas terhadap form NHI. Selama petugas memiliki pengetahuan yang memadai, skrining $\mathrm{NHI}$ dapat dilakukan bersamaan dengan kunjungan neonatal. Selama ini kendala dari pelaksanaan $\mathrm{NHI}$ salah satunya adalah terkait sumber daya manusia (SDM), baik secara kuantitas dan kualitas. Beban kerja petugas gizi yang harus melakukan pelayanan Upaya Kesehatan Perseorangan (UKP) dan Upaya Kesehatan Masyarakat (UKM) bersamaan menjadikan keterbatasan untuk melaksanakan program. Koordinasi yang kurang optimal antar petugas juga menjadi kendala pelaksanaan program.

"Kendalanya tenaga, petugas gizi ngawasi 20 desa dan rawat inap, yang bidan desa tidak saya piketkan di puskesmas, sehingga koordinasi ini jadi PR saya" (Kepala Puskesmas A)

Kualitas SDM terkait pelaksanaan $\mathrm{NHI}$ dan SHK masih belum bagus. Selama ini, untuk pelatihan $\mathrm{NHI}$ dan SHK di tingkat puskesmas belum pernah diselenggarakan. Sedangkan pertemuan rutin khusus untuk $\mathrm{NHI}$ dan SHK baik tingkat dinas kesehatan ataupun puskesmas tidak ada. Materi tentang $\mathrm{NHI}$ biasanya disampaikan saat pertemuan rutin di Dinas Kesehatan Kabupaten Magelang atau puskesmas, bukan dalam pertemuan ataupun pelatihan khusus yang memang membahas hipotiroid kongenital. Sedangkan pelatihan SHK di Dinas Kesehatan Kabupaten Magelang hanya melibatkan perwakilan bidan dari masingmasing puskesmas.

"Untuk menyamakan persepsi belum pernah ada pelatihan" "iya...memang belum ada pelatihan khusus untuk bidan" (Petugas Gizi B)

\section{Implementasi Program}

$\mathrm{NHI}$ menjadi program wajib yang harus dilakukan bidan terhadap semua bayi yang 
baru lahir. Sedangkan SHK tidak dilakukan pada setiap bayi baru lahir, tetapi disesuaikan dengan dana yang tersedia. Dana yang tersedia tidak mencukupi untuk dapat dilakukan pemeriksaan SHK pada semua bayi yang baru lahir dalam satu tahun. Hal ini menyebabkan tidak semua bayi yang lahir dapat dilakukan pemeriksaan SHK.

"SHK itu dulu kita dapat bantuan pertama kali dari pusat, dana APBN, mulai tahun 2012..kita mendapatkan 2 tahun berturut-turut setelah itu dilepas karena kita sudah bisa beralih ke APBD TK II, yang nangani seksi gizi.. sampai hari ini, karena kalo memintakan dana lewat Kesga ndak turun...tapi begitu lewat gizi bisa turun, kita mendapatkan 500 bayi setiap tahun" (Kasie A)

"Ya belum ... kita bayi lahirnya sekitar 19 ribu setahun" (Kasie A)

Pendanaan untuk rujukan kasus juga ada di dinas kesehatan. Jika bayi dideteksi mengarah ke hipotiroid kongenital berdasarkan skrining $\mathrm{NHI}$, maka puskesmas tidak memiliki alokasi anggaran khusus untuk melakukan proses rujukan. Oleh karena itu, jika ada temuan kasus, maka puskesmas hanya memberikan saran rujukan, selanjutnya diserahkan kepada pasien apakah mau dirujuk atau tidak. Pada beberapa kasus, seringkali pasien tidak memeriksakan lebih lanjut karena keterbatasan biaya.

"Dana tergantung program dari dinas. Puskesmas tidak ada anggaran khusus. Kalau ada kasus keputusan terakhir terhadap tindakan kita adalah orang tua sehingga kita hanya berupa saran" (Petugas gizi A)

"Padahal sini itu sok ada seperti itu tapi saya itu bingung malah kalo dia ndak punya uang. Itu kita sudah menyarankan ke GAKl" (Bidan desa A)

Kendala yang dihadapi dalam program SHK adalah darah yang diambil seringkali tidak sesuai dengan aturan. Penolakan dari orang tua karena kekhawatiran proses pengambilan darah juga menjadi kendala tersendri dalam pelaksanaan SHK. Selain itu, beberapa bidan juga mempertanyakan prosedur jika ternyata bayi yang diambil memiliki kelainan darah. Selama ini belum jelas bagaimana prosedur jika ada kasus seperti itu. Meskipun pada akhirnya bidan desa tetap menjalankan program, tetapi ada ketakutan jika terjadi kasus anak dengan kelainan darah, kemudian menuntut pada bidan desa yang melakukan pengambilan darah.

"keluar darahnya sedikit..leh harusnya kan bulet itu..kendalanya disitu." (Kasie A)

"Mungkin ada yang orang tuanya nggak boleh kan nggak tega kan mungkin. Trus nggak jadi diambil. Ya mudah-mudahan nggak ada. Kalau kena bayi yang kena kelainan darah kan bisa bahaya itu ya. Ya itu susah ya, kalau ndilalah ada bayi yang diambil ada kelainan darah kan gimana ya. Itu kan kegiatan berisiko sebenarnya ya. Kalau ada apa2 minta tanggungjawab kita, padahal kita cuma melaksanakan" (Bidan koordinator B)

Dalam pelaksanaan di lapangan, saat kunjungan neonatal, sebagian besar bidan tidak secara terperinci memeriksa tanda-tanda sesuai yang ada di form NHI. Bidan juga tidak mengisi form NHI secara khusus. Hanya jika bidan menemukan ada tanda kelainan, baru akan diisi dalam form dan dilakukan pelaporan ke puskesmas bahwa ada kasus hipotiroid kongenital. Jika tidak, maka akan dilaporkan bahwa bayi dalam keadaan normal. Laporan kunjungan neonatal sendiri tidak secara khusus melampirkan form $\mathrm{NHI}$.

"Sebenarnya kalau yang betul kita ngisi form itu lalu dikumpulkan, tapi kita saat ini kita ada kunjungan MTBM. Jadi KN itu dikasih form MTBM khusus untuk bayi usia 2 bulan ke bawah kita ngisi form itu. Sebenarnya kalau saya pernah lihat form untuk itu.. NHI. Tapi selama ini karena tidak menemukan kelainan jadi tidak diisi. Kalau ada kelainan baru kita isi. Baru kita laporkan di puskesmas. 
Kalau ga ada kasus ga jadi rutininitas. Yang jadi rutinitas itu yang ngisi form MTBM." (Bidan desa C)

"Kunjungan neonatal. Kunjungan neonatal kan harusnya diperiksa selama 3 kali dalam neonatal itu. Nah mereka laporannya di KN itu. Tidak langsung $\mathrm{NHI}$ berapa gitu, yang normal berapa gitu enggak tapi lewat KN. Harusnya KN itu ada NHI nya juga." (Bidan Koordinator $A$ )

\section{PEMBAHASAN}

Hasil penelitian menemukan ada 2 kegiatan skrining hipotiroid kongenital di Kabupaten Magelang, yaitu SHK dan NHI. Faktor pemungkin dan penghambat dalam pelaksanaan skrining hipotiroid kongenital dan temuan integrasi antar program skrining hipotiroid dengan program kesehatan lain telah diidentifikasi. Salah satu prinsip penangan masalah kesehatan, pertumbuhan, dan perkembangan anak adalah semakin dini ditemukan dan ditangani, maka semakin baik prognosisnya. ${ }^{23} \mathrm{Hal}$ ini menyebabkan pentingnya mengevaluasi pelaksanaan program skrining kesehatan anak agar tepat waktu dan tepat dalam pelaksanaannya.

Penelitian ini mencatat beberapa kendala terkait pelaksanaan skrining hipotiroid dengan SHK dan NHI, yaitu dari aspek sumber daya manusia dan implementasi. Hambatan terkait SDM meliputi kualitas, kuantitas, dan koordinasi SDM dari tingkat penanggung jawab dan pelaksana program. Kurangnya kualitas SDM pelaksana program skrining antara lain disebabkan karena pelatihan $\mathrm{NHI}$ dan SHK di tingkat puskesmas belum pernah diselenggarakan, sehingga bidan desa belum terpapar pelatihan secara langsung. Hal ini sejalan dengan penelitian di Kabupaten Wonosobo dan Temanggung yang menunjukkan kurangnya pelatihan pada bidan pelaksana skrining hipotiroid, baik SHK maupun skrining dengan form $\mathrm{NHI} .{ }^{24,25} \mathrm{Hal}$ ini sangat terasa pada skrining SHK yang memerlukan ketrampilan dan presisi pengambilan sampel. ${ }^{15}$ Penelitian juga menunjukkan bahwa intervensi dapat meningkatkan pengetahuan bidan dan penerapan MTBM, SHK, dan NHI. ${ }^{25,26}$

Kendala dalam SDM pelaksana ini menyebabkan kelemahan dalam implementasi program. Sejalan dengan evaluasi SHK di Provinsi DIY,14 penelitian ini juga menemukan ketepatan waktu diagnosis hipotiroid kongenital juga masih terlambat. Kesulitan dalam pengambilan darah sesuai standar SHK juga ditemukan dalam penelitian ini, sehingga dimungkinkan sampling yang cakupannya terbatas masih ditambahkan dengan kualitas sampel yang tidak memadai untuk dianalisis. Hal ini sejalan dengan penelitian di Malang yang menunjukkan dengan keterbatasan cakupan, masih ditemukan cukup banyak sampel SHK yang kurang memenuhi syarat sehingga tidak dapat dilakukan analisis. ${ }^{15}$

Deteksi dini hipotiroid melalui program SHK juga dilakukan pada bayi baru lahir usia 3-5 hari. Namun, pemegang program di Dinas Kesehatan Kabupaten Magelang juga memberi keleluasaan pengambilan darah sampai maksimal usia 1 bulan. Pelaksanaan SHK di Indonesia relatif baru dibandingkan dengan negara maju. Belgia yang telah menerapkan SHK universal sejak tahun 1976, telah berhasil secara konsisten menerapkan SHK pada bayi usia 3-5 hari. ${ }^{27}$ Bahkan di Finlandia, median dimulainya terapi kasus HK adalah hari ke- $6 .{ }^{28}$ Kendala dalam penelitian ini adalah terkait prosedur rujukan yang belum jelas. Hal ini sejalan dengan penelitian sebelumnya yang menyebutkan bahwa alur jejaring kerja sama program SHK yang kurang efisien mengakibatkan keterlambatan waktu pelayanan, terutama pada waktu penyampaian dan tindak lanjut hasil tes SHK. ${ }^{14}$ Pada penelitian ini, Kabupaten Magelang memiliki keuntungan, yaitu di wilayah kerjanya terdapat klinik BP2GAKI Magelang yang menangani pemeriksaan dan 
penanganan kasus hipotiroid tanpa biaya untuk anak-anak. Puskesmas biasanya hanya memberikan saran rujukan yang ditindaklanjuti sendiri oleh keluarga pasien ke klinik BP2GAKI Magelang.

Semakin meluasnya negara yang melakukan SHK secara universal menyebabkan tidak banyak penelitian terbaru yang mengkaji skrining tanda-tanda klinis HK dalam kaitannya dengan ketepatan diagnosis. Beberapa penelitian menyebutkan bahwa sebagian besar HK tidak menunjukkan gejala klinis di awal kelahirannya, sebagian menunjukkan gejala klinis non spesifik, bahkan tanpa gejala klinis sama sekali. ${ }^{28,29}$ Meskipun demikian, terdapat hubungan signifikan antara derajat keparahan HK berdasar indikator biokimia hipotiroidisme dengan simtom klinis yang dimunculkan, dan ketika simtom klinis tersebut muncul, maka pemeriksaan dengan indikator biokimia lanjutan perlu dilakukan untuk menegakkan diagnosis dan dilakukan terapi sedini mungkin. ${ }^{28,30,31}$ Penelitian di Denmark, sebelum dilakukan SHK universal dan seorang anak didiagnosis berdasarkan tanda klinis, kasus HK dilaporkan pada prevalensi 1:5800 sampai 1: 6900, dibandingkan dengan prevalensi SHK 1:3000 sampai 1:4000. Penelitian ini juga mencatat, pada kondisi kepatuhan SOP yang belum ideal, dan bidan yang belum terpapar pelatihan, bidan di 2 dari 4 puskesmas yang dijadikan responden melaporkan penemuan kasus HK berdasarkan skrining tanda klinis yang terkonfirmasi dengan pemeriksaan lanjut biokimia. Situasi yang sama dilaporkan dalam penelitian kualitatif di Wonosobo. ${ }^{24}$

Hasil penelitian mengidentifikasi faktor pendukung terlaksananya program skrining hipotiroid adalah dari sisi kebijakan dan implementasi. Hasil penelitian menunjukkan bahwa, secara kebijakan, setiap anak baru lahir telah ditargetkan untuk mendapatkan skrining tanda klinis hipotiroid kongenital dengan form
NHI. Hal ini merupakan potensi penting dalam pelaksanaan integrasi, karena mempermudah integrasi proses pelaksanaan dan pelaporan skrining hipotiroid kongenital dengan MTBM. Indikator cakupan dan pelaporan MTBM secara nasional telah menjadi indikator pelayanan kesehatan yang bersifat nasional. Terdapat perbedaan persepsi di tingkat penanggung jawab program Dinas Kesehatan Kabupaten Magelang, apakah program merupakan inisiatif Dinas Kesehatan Kabupaten Magelang, atau program yang sudah ditetapkan oleh Dinas Kesehatan Provinsi Jawa Tengah untuk dilaksanakan di seluruh kabupaten/kota dengan riwayat defisiensi iodium di Provinsi Jawa Tengah.

Faktor pendukung lain adalah implementasi integrasi skrining hipotiroid dengan MTBM. Penelitian menunjukkan skrining tanda klinis dilakukan $\mathrm{NHI}$ bidan desa terintegrasi dengan MTBM yang merupakan bagian dari Manajemen Terpadu Balita Sakit Berbasis Masyarakat (MTBS-M) diatur dalam Permenkes RI Nomor 70 Tahun 2013. ${ }^{32}$ Integrasi SHK, $\mathrm{NHI}$, dan MTBM berdasarkan penelitian ini sangat potensial untuk diterapkan dengan sasaran NHI dan MTBM universal, serta SHK. Manajemen Terpadu Bayi Muda adalah bagian dari Manajemen Terpadu Balita Sakit yang merupakan pedoman tata laksana untuk bayi muda (umur kurang dari 2 bulan) baik yang sehat maupun sakit. Penanganan bayi muda, diutamakan pelaksanaannya oleh bidan di desa pada saat kunjungan neonatal Paket MTBS-M bayi muda umur 0-2 bulan terdiri dari: (1) Perawatan esensial bayi baru lahir (essential newborn care), (2) Pengenalan tanda bahaya bayi baru lahir serta persiapan rujukan, (3) Penatalaksanaan Bayi Berat Lahir Rendah (BBLR), dan (4) Penatalaksanaan infeksi pada bayi baru lahir. ${ }^{33,34}$ Deteksi tanda klinis hipotiroid dapat dimasukkan dalam paket pengenalan tanda bahaya bayi baru lahir. Fisibilitas integrasi skrining hipotiroid dengan MTBM terbukti dari 
aspek output dan proses integrasi. Berdasarkan aspek output, keberhasilan integrasi terbukti dengan ditindaklanjutinya satu kasus temuan $\mathrm{HK}$ melalui skrining $\mathrm{NHI}$ pada kunjungan neonatus yang dilaksanakan oleh bidan desa. Berdasarkan aspek proses, keberhasilan integrasi terlihat dari praktek pelaksanaan, yaitu form $\mathrm{NHI}$ masuk dalam buku KIA dan pengambilan blood spot sampel SHK dilakukan pada kunjungan bayi muda, dari segi pelaporan, juga NHI dan MTBM yang sama-sama bersifat universal dilaporkan terintegrasi dalam manajemen terpadu bayi muda. Fisibilitas integrasi ini juga didukung dengan bukti penelitian tentang faktor pendukung keberhasilan MTBM. Hasilnya menunjukkan bahwa kualitas pelaksanaan MTBM tidak terkait dengan tambahan beban kerja maupun reward, hal ini mendukung fisibilitas pelaksanaan skrining hipotiroid neonatal dengan MTBM. ${ }^{34}$

Pada sisi lain, integrasi skrining $\mathrm{NHI}$ atau skrining hipotiroid kongenital berdasarkan tanda-tanda klinis dengan MTBM juga memiliki kelemahan, karena sifat kasus HK yang sebagian besar tidak menunjukkan tanda klinis pada minggu awal. Hal ini memungkinkan bayi dengan hipotiroid kongenital yang memunculkan tanda-tanda klinis sesudah usia 3 bulan tidak terjaring pada kunjungan MTBM. Studi di Denmark menemukan hanya sekitar 10 persen kasus terdiagnosis pada awal kehidupan, 35 persen pada 3 bulan dan 70 persen di bawah usia satu tahun. Beberapa kasus terdiagnosis pada usia 3 atau 4 tahun. Studi retrospektif di Turki yang menganalisis 1.000 kasus HK melalui diagnosis medis atau gejala klinis, ratarata terdiagnosis pada usia 49 bulan. Hanya 3,1 persen terdiagnosis di periode perinatal, serta 55,4 persen di atas usia 2 tahun. Studi di Turki tidak menyebutkan apakah gejala klinis tersebut merupakan hasil skrining sistematis atau berdasarkan kunjungan pasien ke fasilitas pelayanan kesehatan, sehingga belum jelas pada usia berapa onset gejala klinis timbul, alih-alih usia awal dilakukan pemeriksaan oleh klinisi. ${ }^{30}$ Oleh karena itu, diperlukan integrasi lebih lanjut dengan program skrining kesehatan pada usia anak yang lebih tinggi.

Kelemahan ini dapat ditutupi dengan menambahkan integrasi skrining $\mathrm{HK}$ pada program stimulasi, deteksi, dan intervensi dini tumbuh kembang yang mencakup sasaran anak usia 0-72 bulan, ${ }^{35}$ sehingga integrasi skrining kasus HK dimasukkan dalam kerangka optimalisasi kesehatan, pertumbuhan, dan perkembangan anak di daerah dengan riwayat defisiensi iodium. Keberhasilan program deteksi dan intervensi dini yang terintegrasi dapat menjadi faktor protektif bagi risiko masalah pertumbuhan dan perkembangan anak di daerah replete endemik GAKI, jika dapat dilaksanakan dengan baik. Pada penelitian ini, integrasi temuan tanda klinis hipotiroid pada posyandu baru diungkapkan sebatas kemungkinan, belum terbukti dengan temuan kasus kretin atau hipotiroid kongenital berdasar pemeriksaan di posyandu.

Mengingat kebijakan skrining $\mathrm{NHI}$ universal terintegrasi MTBM ini masih merupakan inisiatif daerah, maka dapat diasumsikan bahwa masih sedikit daerah yang menerapkan skrining $\mathrm{NHI}$ universal pada setiap bayi baru lahir. Upaya Kabupaten Magelang untuk menjadikan program skrining kasus kretin dengan form $\mathrm{NHI}$ terintegrasi dengan kunjungan neonatus dapat dijadikan pembelajaran untuk menjangkau seluruh anak baru lahir dalam deteksi dini HK, baik terkait GAKI maupun tidak, sebelum SHK dapat diterapkan secara universal.

Keunggulan penelitian ini adalah menyampaikan temuan tentang pelaksanaan program skrining hipotiroid, terutama dengan form $\mathrm{NHI}$ yang memungkinkan menjangkau semua bayi baru lahir dan integrasinya dengan program MTBM yang lebih mapan dan rutin dilaksanakan. Penelitian sebelumnya menunjukkan, deteksi dini melalui SHK belum menjadi program rutin pemerintah sehingga 
kasus hipotiroid kongenital belum banyak dapat dikelola secara tepat dan berkesinambungan. ${ }^{13}$ Hal tersebut juga dikonfirmasi dalam penelitian ini. Komitmen pendanaan mandiri SHK melalui APBD pada 500 bayi per tahun masih jauh dari jumlah bayi lahir per tahun di Kabupaten Magelang. Perbedaannya, penelitian ini menemukan adanya upaya untuk menjangkau semua bayi baru lahir dalam skrining hipotiroid melalui deteksi tanda klinis dengan form $\mathrm{NHI}$. Upaya menjamin terlaksananya program skrining hipotiroid dilakukan melalui integrasi dengan program yang lebih mapan (MTBM), yaitu mengintegrasikan kegiatan dan form $\mathrm{NHI}$ dalam MTBM. Upaya integrasi ini juga telah berhasil, terbukti dengan ditindaklanjutinya satu kasus temuan HK melalui skrining $\mathrm{NHI}$ pada kunjungan neonatal yang dilaksanakan oleh bidan desa.

Kelemahan penelitian ini adalah belum dilakukannya kajian mendalam tentang MTBM, karena dimungkinkan bahwa MTBM juga belum dilaksanakan secara optimal. Penelitian sebelumnya menunjukkan bahwa hambatan juga dialami bidan dalam penerapan algoritma MTBM. Beberapa penelitian evaluasi pelaksanaan MTBM menemukan masalah serupa terkait ketidakpatuhan SOP serta keterampilan SDM karena cakupan pelatihan yang rendah, kurangnya supervisi, dan kendala terkait kelengkapan sarana. ${ }^{26,36,37}$ Penelitian selanjutnya diharapkan dapat mengevaluasi kualitas pelaksanaan MTBM dengan lebih baik, sehingga diperoleh gambaran lebih jelas dan terperinci terkait integrasi dan kualitas pelaksanaan program.

\section{KESIMPULAN}

Terdapat dua program skrining hipotiroid yang dilaksanakan di Kabupaten Magelang, yaitu SHK pada 500 bayi per tahun dan skrining dengan form $\mathrm{NHI}$ pada setiap bayi baru lahir. Faktor penghambat program, dari aspek
SDM adalah bidan desa belum mendapatkan pelatihan SHK dan $\mathrm{NHI}$, kurangnya supervisi/ koordinasi, dan prosedur rujukan penemuan kasus HK belum jelas. Hal ini menyebabkan sebagian implementasi program dan tindak lanjut belum mengikuti standar/pedoman. Faktor pemungkin terlaksananya program dari aspek kebijakan Dinas Kesehatan Kabupaten Magelang adalah komitmen pendanaan mandiri SHK melalui APBD, kebijakan skrining form $\mathrm{NHI}$ universal, serta kebijakan mengintegrasikan skrining hipotiroid dengan MTBM. Pada aspek implementasi, program SHK dan $\mathrm{NHI}$ telah diimplementasikan oleh bidan dan petugas gizi di tingkat puskesmas sebagai penanggung jawab dan bidan desa sebagai pelaksana program. Faktor pemungkin lain adalah diintegrasikannya program skrining hipotiroid kongenital dengan MTBM pada kunjungan neonatal. Fisibilitas integrasi terbukti dari penemuan kasus $\mathrm{HK}$ dengan skrining $\mathrm{NHI}$ terintegrasi MTBM.

\section{SARAN}

Upaya Kabupaten Magelang menjadikan program skrining kasus kretin dengan form $\mathrm{NHI}$ pada bayi yang diintegrasikan dengan program MTBM pada kunjungan neonatal dapat dijadikan pembelajaran untuk menjangkau seluruh anak baru lahir dalam deteksi dini HK, baik terkait GAKI maupun tidak, sebelum SHK dapat diterapkan secara universal. Penelitian selanjutnya diharapkan dapat menganalisis pelatihan terpadu SHK, NHI, MTBM pada bidan pelaksana, khususnya bidan desa. Agar berjalan efektif, pelatihan dilaksanakan berbasis puskesmas, mengingat selama ini pelatihan dilakukan di dinas kesehatan. Diharapkan, setiap bidan desa mampu melaksanakan skrining hipotiroid terintegrasi dengan MTBM sesuai pedoman. 


\section{UCAPAN TERIMA KASIH}

Penulis mengucapkan terima kasih kepada Badan Penelitian dan Pengembangan Kesehatan yang memberikan pendanaan untuk riset ini. Kasie Gizi, KIA, para bidan, dan petugas gizi di Kabupaten Magelang yang bersedia memberikan waktu serta wawasannya. Semoga tulisan ini memberikan manfaat untuk mengoptimalkan program kesehatan.

\section{DAFTAR PUSTAKA}

1. Christian P, Mullany LC, Hurley KM, Katz J, Black RE. Nutrition and Maternal, Neonatal, and Child Health. Semin Perinatol. 2015;39(5):361-72.

2. Walker SP, Wachs TD, GranthamMcgregor S, Black MM, Nelson CA, Huffman SL, et al. Inequality in Early Childhood: Risk and Protective Factors for Early Child Development. Lancet. 2011;378(9799):1325-38.

3. Melse-boonstra A, Jaiswal N. lodine Deficiency in Pregnancy, Infancy and Childhood and Its Consequences for Brain Development. Best Pract Res Clin Endocrinol Metab. 2010;24(1):29-38.

4. Çaylan N, Tezel B, Özbaş S, Şahin N, Aydın Ş, Acıcan D, et al. Neonatal ThyroidStimulating Hormone Screening as a Monitoring Tool for lodine Deficiency in Turkey. J Clin Res Pediatr Endocrinol. 2016;8(2):187-91.

5. Kaiserman I, Siebner R, Sack J. Regional and Temporal Fluctuations in the Incidence of Congenital Hypothyroidism in Israel. $J$ Endocrinol Invest. 1995;18(8):595-601.

6. Khanjani N, Ahmadzadeh A, Bakhtiari B, Madadizadeh F. The Role of Season and Climate in the Incidence of Congenital Hypothyroidism in Kerman Province, Southeastern Iran. J Pediatr Endocrinol Metab. 2017;30(2):149-57.
7. Mehran L, Yarahmadi S, Khalili D, Nazeri $P$, Delshad $H$, Abdollahi $Z$, et al. The Impact of lodine Status on the Recall Rate of the Screening Program for Congenital Hypothyroidism: Findings from Two National Studies in Iran. Nutrients. 2017;9(11):1194.

8. Kapil U, Jain V, Kabra M, Pandey RM, Sareen N, Khenduja P. Prevalence of Neonatal Hypothyroidism in Kangra Valley, Himachal Pradesh. Eur J Clin Nutr. 2014;68(6):748-9.

9. Zoeller RT, Rovet J. Timing of Thyroid Hormone Action in the Developing Brain: Clinical Observations and Experimental Findings. J Neuroendocrinol. 2004;16(10):809-18.

10. Nurcahyani YD, Mulyantoro DK, Sukandar PB, Samsudin M, Ihsan N. Diagnosis Hipotiroid pada Anak Batita di Daerah Endemik GAKI. MGMI. 2017;8(2):89-102.

11. Kementerian Kesehatan RI. Peraturan Menteri Kesehatan Republik Indonesia Nomor 78 Tahun 2014 tentang Skrinning Hipotiroid Kongenital. Jakarta: Kementerian Kesehatan Rl;2014.

12. Dirjen Bina Gizi dan Kesehatan Ibu dan Anak, Kementerian Kesehatan RI. Pedoman Skrining Hipotiroid Kongenital. 2012. Jakarta: Dirjen Bina Gizi dan Kesehatan Ibu dan Anak;2012.

13. Wirawan A, Suryawan B. Tumbuh Kembang Anak Hipotiroid Kongenital yang Diterapi Dini dengan Levo-tiroksin dan Dosis Awal Tinggi. Sari Pediatr. 2013;15(2):69-74.

14. Anggraini R, Patria SY, Julia M. Ketepatan Waktu Pelayanan Skrining Hipotiroidism Kongenital di Yogyakarta. Sari Pediatr. 2017;18(6):436-42.

15. Widayati, Susyati, Purwanti. Uji Saring Hipotiroid Kongenital Melalui Kadar Neonatal - TSH dengan Teknik IRMA. Prosiding Pertemuan IImiah Fungsional Teknis Non 
Peneliti;19 Desember 2006; Batan; 2006. p 165-72.

16. Atmarina D. Peran Tenaga Kesehatan dalam Implementasi Kebijakan Stimulasi Deteksi dan Intervensi Dini Tumbuh Kembang Anak di Kabupaten Pekalongan. Tesis. Semarang: Program Pascasarjana Prodi Kedokteran Keluarga Universitas Sebelas Maret Surakarta, 2011.

17. Kementerian Kesehatan RI. Pedoman Deteksi Dini Kretin bagi Petugas Kesehatan. Jakarta: Kementerian Kesehatan Rl;2014.

18. Utami S, Nursalam, Hargono R, Susilaningrum R. Kinerja Bidan dalam Deteksi Dini Penyimpangan Tumbuh Kembang Anak. Ners. 2016;11(2):201-9.

19. Frank MR. The Health Compliance Model-II. Behav Anal. 2005;6(1):27-43.

20. Hsieh HF, Shannon SE. Three Approaches to Qualitative Content Analysis. Qual Health Res. 2005;15(9):1277-88.

21. Bengtsson M. How to Plan and Perform a Qualitative Study Using Content Analysis. Nursing Plus Open. 2016;2:8-14.

22. Ahmad J. Desain Penelitian Analisis Isi (Content Analysis). UIN Syarif Hidayatullah. Jakarta;2018:1-20. Diunduh dari:

https://www.researchgate.net/profile/Jumal_ Ahmad/publication/325965331_Desain_ Penelitian_Analisis_Isi_Content_Analysis/ links/5b305090a6fdcc8506cb8b21/DesainPenelitian-Analisis-Isi-Content-Analysis.pdf, tanggal 3 Juni 2020.

23. Woolfenden S, Posada N, Krchnakova R, Crawford J, Gilbert J, Jursik B, Sarkozy V, et al. Equitable Access to Developmental Surveillance and Early Intervention Understanding The Barriers for Children from Culturally and Linguistically Diverse (CALD) Backgrounds. Health Expect. 2015;18(6):3286-301.
24. Martiyana C, Samsudin M. Studi Kualitatif Deteksi Dini GAKI oleh Bidan Desa di Kabupaten Wonosobo. MGMI. 2011;2(2):158-69.

25. Martiyana C, Samsudin M. Pengetahuan dan Praktek Bidan Desa Pasca Pelatihan Deteksi Dini Kasus GAKI di Kabupaten Temanggung. MGMI. 2014;6(1):37-52.

26. Putra IWGAE, Djuwita R. Peningkatan Pengetahuan dan Penerapan Manajemen Terpadu Bayi Muda oleh Bidan Desa di Kabupaten Temanggung Tahun 2012. Arc Com Heal. 2012;1(2):98-108.

27. Vandevijvere S, Coucke W, Vanderpas J, Trumpff C, Fauvart M, Schoos R, et al. Neonatal Thyroid-Stimulating Hormone Concentrations in Belgium : AUseful Indicator for Detecting Mild lodine Deficiency?. PLoS One. 2012;7(10):3-8.

28. Virtanen M. Manifestations of Congenital Hypothyroidism during the 1st Week of Life. Eur J Pediatr. 1988;147(3):270-4.

29. Smolkin T, Blazer S, Makhoul IR. Rare Presentations of Congenital Hypothyroidism. IMAJ. 2011;13:779-80.

30. Pezzuti I, DeLima P, Dias V. Congenital Hypothyroidism: the Clinical Profile of Affected Newborns Identified by the Newborn Screening Program of the State of Minas Gerais, Brazil. J Pediatr. 2009;85(1):72-9.

31. Grant DB, Smith I, Fuggle PW, Tokar S, Chapple J. Congenital Hypothyroidism Detected by Neonatal Screening: Relationship Between Biochemical Severity and Early Clinical Features. Arch Dis Child. 1992;67:87-90.

32. Kementerian Kesehatan RI. Peraturan Menteri Kesehatan Republik Indonesia Nomor 70 Tahun 2013 tentang Penyelenggaraan Manajemen Terpadu Balita Sakit Berbasis Masyarakat. Jakarta: Kementerian Kesehatan RI;2014. 
33. Dirjen Bina Gizi dan Kesehatan Ibu dan Anak, Kementerian Kesehatan RI. Pedoman Penyelenggaraan Manajemen Terpadu Balita Sakit Berbasis Masyarakat (MTBS-M). 2014. Jakarta: Kementerian Kesehatan RI.

34. Iraningsih W, Azinar M. Praktik Bidan dalam Penggunaan Algoritma Manajemen Terpadu Bayi Muda Pada Kunjungan Neonatal. Unnes J Public Heal. 2017;6(1):1.

35. Kementerian Kesehatan RI. Peraturan Menteri Kesehatan Republik Indonesia Nomor 66 Tahun 2014 tentang Pemantauan Pertumbuhan, Perkembangan, dan
Gangguan Tumbuh Kembang Anak. Jakarta: Kementerian Kesehatan RI;2014.

36. Kiplagat A, Musto R, Mwizamholya D, Morona D. Factors Influencing The Implementation of Integrated Management of Childhood Illness (IMCI) by Healthcare Workers at Public Health Centers and Dispensaries in Mwanza, Tanzania. BMC Public Health. 2014;14(277):1-10.

37. Titaley C. Implementation of $I \mathrm{MCl}$ in West Java Province, Indonesia. J Public Health. 2014;3(2):161-70. 